A

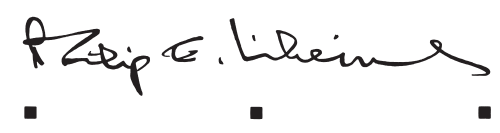

$\mathrm{B} \mathrm{O} \mathrm{O} \mathrm{K}$

The Philip E. Lilienthal imprint

honors special books

in commemoration of a man whose work at University of California Press from 1954 to 1979

was marked by dedication to young authors and to high standards in the field of Asian Studies.

Friends, family, authors, and foundations have together endowed the Lilienthal Fund, which enables UC Press

to publish under this imprint selected books

in a way that reflects the taste and judgment

of a great and beloved editor. 
The publisher gratefully acknowledges the generous support of the Philip E. Lilienthal Asian Studies Endowment Fund of the University of California Press Foundation, which was established by a major gift from Sally Lilienthal. 
Rifle Reports 
This page intentionally left blank 


\section{Rifle Reports}

A Story of Indonesian Independence

\section{Mary Margaret Steedly}

따

UNIVERSITY OF CALIFORNIA PRESS

Berkeley • Los Angeles • London 
University of California Press, one of the most distinguished university presses in the United States, enriches lives around the world by advancing scholarship in the humanities, social sciences, and natural sciences. Its activities are supported by the UC Press Foundation and by philanthropic contributions from individuals and institutions. For more information, visit www.ucpress. edu.

University of California Press Berkeley and Los Angeles, California

University of California Press, Ltd.

London, England

(C) 2013 by The Regents of the University of California

Library of Congress Cataloging-in-Publication Data

Steedly, Mary Margaret, I946-.

Rifle reports : a story of Indonesian independence / Mary Margaret Steedly.

p. $\mathrm{cm}$.

Includes bibliographical references and index.

ISBN 978-0-520-27486-o (cloth : alk. paper)

ISBN 978-0-520-27487-7 (pbk. : alk. paper)

I. Indonesia-History-Revolution, I945-I949Personal narratives, Indonesian. 2. Sumatera Utara (Indonesia)-History. 3. Karo-Batak (Indonesian people)-History. I. Title.

DS644.S73 2013

$959.803^{\prime} 5-\mathrm{dc} 23$

2012047748

Manufactured in the United States of America

$\begin{array}{lllllllll}2 \text { I } & 20 & \text { I9 } & \text { I } 8 & \text { I7 } & \text { I6 } & \text { I5 } & \text { I4 } & \text { I3 }\end{array}$

In keeping with a commitment to support environmentally responsible and sustainable printing practices, UC Press has printed this book on 50-pound Enterprise, a $30 \%$ postconsumer waste, recycled, deinked fiber that is processed chlorine-free. It is acid-free and meets all ANSI/NISO (Z 39.48) requirements. 
This book is dedicated, with respect and admiration, to all the eager girls and daring boys of Karoland's 1945 generation, who imagined independence in myriad ways and saw how it turned out. 
This page intentionally left blank 